\title{
Deteksi Dini Malnutrisi pada Anak dengan Metode Aspen di Aisyah Ranting Sumbang
}

\author{
Atika Dhiah Anggraeni ${ }^{1}$, Destiya Dwi Pangestika ${ }^{2}$, Arif Hendra Kusuma ${ }^{3}$ \\ S1 Ilmu Keperawatan, Universitas Muhammadiyah Purwokerto ${ }^{1,2}$ \\ D3 Keperawatan, STIKES Serulingmas Cilacap ${ }^{3}$ \\ tika_ners87@yahoo.com,pdestiyadwi@roket.com, arifsermas@gmail.com
}

\begin{abstract}
Abstrak
Malnutrisi adalah menggambarkan kekurangan, kelebihan atau ketidakseimbangan zat gizi yang menghasilkan efek tidak baik pada komposisi tubuh, fungsi dan outcome klinis. Penilaian status gizi berkala merupakan upaya dalam deteksi dini malnutrisi sehingga dapat dilakukan tindakan yang semestinya dan dapat dilakukan berkala oleh orang tua karena penilaian status gizi oleh tenaga kesehatan hanya dilakukan pada saat anak sakit. American Society for Parenteral and Enteral Nutrition (ASPEN) dalam Malnutrition Awareness Week mengeluarkan panduan untuk mendeteksi risiko malnutrisi pada anak oleh orang tua. Panduan tersebut lebih praktis, waktu lebih singkat serta mudah dipahami. Tujuan kegiatan pengabdian ini adalah untuk melatih ibu agar dapat melakukan deteksi dini malnutrisipada anak dengan metode Aspen. Sasaran kegiatan ini adalah anggota Aisyah ranting sumbang berjumlah 30 orang. Hasil dari kegiatan Ipteks bagi Masyarakat (IbM) ini adalah adanya peningkatan pengetahuan dan ketrampilan dari anggota aisyah. Upaya serupa dapat dilakukan dengan memonitoring setiap bulan terhadap anak untuk mengetahui tingkat pertumbuhan dan perkembangan serta kegiatan lain yang dapat menunjang peningkatan status gizi yaitu dengan pendidikan kesehatan bertema asupan nutrisi gizi seimbang.
\end{abstract}

Kata kunci: malnutrisi, anak, ASPEN

\begin{abstract}
Malnutrition is describing a deficiency, excess or imbalance of nutrients that produce adverse effects on body composition, function and clinical outcome. Periodic nutritional status assessment is an effort in early detection of malnutrition so that appropriate and periodic actions can be taken by parents because the assessment of nutritional status by health personnel is only carried out when the child is sick. The American Society for Parenteral and Enteral Nutrition (ASPEN) in Malnutrition Awarness Week issued a guide to detect the risk of malnutrition in children by parents. The guide is more practical, takes less time and is easy to understand. The purpose of this IbM (Science and Technology for the community) is to train mothers to be able to detect malnutrition in children early using the Aspen method.The target of this activity is 30 members of the aisyah branch donation. The result of this IbM is an increase in the knowledge and skills of Ayesha's members. Similar efforts can be made by monitoring children every month to determine the level of growth and development and other activities that can support the improvement of nutritional status, namely health education with the theme of balanced nutritionintake.
\end{abstract}

Keywords: malnutrition, child, ASPEN 


\section{PENDAHULUAN}

Masa balita merupakan masa dimana terjadi pertumbuhan dan perkembangan yang sangat pesat. Balita di atas satu tahun sudah mulai mengerti bahasa dan memiliki rasa keingintahuan yang sangat besar. Hal ini membuat balita menjadi sangat aktif dan membutuhkan energi yang lebih banyak. Apabila asupan makanan balita tidak mencukupi akan menimbulkan malnutrisi. Balita yang aktif juga lebih mudah terpapar oleh mikroorganisme penyebab penyakit. Apabila balita sering sakit maka risiko malnutrisi menjadi lebih besar (Candra, 2017). Adapun salah satu penyebabnya adalah kebutuhan gizi yang tidak terpenuhi. Keadaan gizi balita akan mempengaruhi tingkat kesehatan dan harapan hidup yang merupakan salah satu unsur utama dalam penentuan keberhasilan pembangunan negara atau yang sering disebut dengan istilah Human Development Index (HDI). Malnutrisi merupakan salah satu masalah kesehatan utama yang menjadi perhatian internasional, khususnya di negaraberkembang.

Malnutrisi adalah menggambarkan kekurangan, kelebihan atau ketidakseimbangan zat gizi yang menghasilkan efek tidak baik pada komposisi tubuh, fungsi dan outcome klinis. Serta menurut Pricilia et al. (2015) malnutrisi atau gizi buruk merupakan masalah yang perlu penanganan yang serius karena gizi buruk dapat mempengaruhi kualitas sumber dayamanusia.

World Health Organization (WHO) menyebutkan sekitar 50\% dari 10 juta kematian anak di bawah usia 5 tahun di negara berkembang, berkaitan dengan defisiensi energi dan protein. Hasil Riskesdas menunjukkan adanya peningkatan prevalensi balita gizi kurang dan buruk secara nasional, prevalensi berat-kurang pada tahun 2013 adalah 19,6\%, terdiri dari 5,7\% gizi buruk dan 13,9\% gizi kurang. Jika dibandingkan dengan angka prevalensi nasional tahun 2007 $(18,4 \%)$ dan tahun $2010(17,9 \%)$ terlihat meningkat. Perubahan terutama pada prevalensi gizi buruk yaitu dari 5,4\% tahun 2007, 4,9\% pada tahun 2010, dan 5,7\% tahun 2013. Sedangkan prevalensi gizi kurang naik sebesar 0,9\% dari 2007 dan 2013.

Status gizi merupakan faktor penting dalam menjamin perkembangan dan pertumbuhan seorang anak yang optimal. Pada periode tumbuh kembang, terutama usia 6-60 bulan, anak rentan terhadap kekurangan asupan gizi. Hal tersebut mengakibatkan anak jatuh ke dalam kondisi malnutrisi dengan berbagai gejala danpenyulitnya.

Salah satu tanda gizi buruk balita adalah berat badan balita di bawah garis merah dalam Kartu Menuju Sehat (KMS) balita. Masalah gizi buruk balita merupakan masalah yang sangat serius, apabila tidak ditangani secara cepat dan cermat dapat berakhir pada kematian. Gizi buruk lebih rentan pada penyakit akibat menurunnya daya tahan tubuh, pertumbuhan dan perkembangan yang tidak optimal, sampai pada kematian yang akan menurunkan kualitas generasi muda mendatang. Hal ini telah membukakan mata kita bahwa anak balita sebagai 
sumber daya untuk masa depan mempunyai masalah yang sangatbesar.

Penilaian status gizi berkala merupakan upaya dalam deteksi dini malnutrisi sehingga dapat dilakukan tindakan yang semestinya. Penilaian status gizi anak sering sekali hanya dilakukan oleh tenaga kesehatan pada saat anak dibawa berobat karena penyakit lain. Seyogyanya, penilaian gizi dilakukan berkala oleh orang tua karena penilaian status gizi oleh tenaga kesehatan hanya dilakukan pada saat anak sakit. Menentukan status gizi seorang anak diperlukan pemeriksaan lengkap meliputi anamnesis, pemeriksaan fisis lengkap, pengukuran antropometri, dan laboratorium yang hanya bisa dilakukan oleh tenaga kesehatan dan tidak bisa dilakukan oleh orang tua.

American Society for Parenteral and Enteral Nutrition (ASPEN) dalam Malnutrition Awareness Week mengeluarkan panduan untuk mendeteksi risiko malnutrisi pada anak oleh orangtua. Panduan tersebut lebih praktis, waktu lebih singkat serta mudah dipahami. Dengan deteksi dini risiko malnutrisi oleh orang tua, diharapkan orang tua akan segera membawa anak berobat untuk mendapat tindakan yang seharusnya.

Kusioner ASPEN yang terdiri dari 9 pertanyaan mengenai apakah anak mengalami penurunan berat badan (BB), peningkatan BB yang lambat, atau memiliki BB yang kurang; anak tidak bertambah tinggi; ukuran pakaian anak tidak bertambah; jumlah makan lebih sedikit dari biasanya; tidak berselera makan atau tidak nafsu makan; menggunakan selang makan atau mekan makanan khusus; anak tidak mau makan karena ada masalah diperut; anak kurang aktif dan jarang bermain dari biasanya; dan lebih tidur dari biasanya. Subjek yang menjawab minimal satu jawaban "iya" dari sembilan pertanyaan dalam kuesioner tersebut dimasukkan ke dalam subjek yang berisiko mengalami malnutrisi. Sebagai baku emas untuk menilai kinerja metode ASPEN adalah status antropometri BB menurut panjang badan (PB) atau tinggi badan (TB) (BB/PB atau BB/TB) berdasarkan WHO dengan nilai Z-score <-1 SD dinilai sebagai anak risiko malnutrisi yang akan dibandingkan dengan penilaian orang tua menurut metode ASPEN (Prita et al., 2019).

Hasil observasi dan wawancara dengan anggota aisyah ranting Beji mendapatkan hasil bahwa anggota aisyah belum pernah terpapar penegetahuan tentang malnutrisi. Beberapa juga mengatakan bahwa sekarang deteksi dini penting dilakukan untuk mencegah kejadian seperti stunting, gizi buruk maupun obesitas. Anggota aisyah juga ingin memberikan kontribusi untuk pencegahan hal tersebut. Berdasarkan masalah tersebut makan penulis tertarik untuk melaksanakan pengabdian tentang deteksi dini mal nutrisi dengan metode ASPEN. Bentuk kegiatan pengabdian adalah berupa kegiatan transfer IPTEK ke masyarakat yang dikenal dengan nama IbM. Tujuan kegiatan IbM ini adalah untuk melatih ibu agar dapat melakukan 
deteksi dini malnutrisi pada anak dengan metode Aspen.

\section{MASALAH}

Berdasarkan analisis situasi yang dijabarkan diatas, didapatkan beberapa permasalahan :

1) Angka kejadian malnutrisi semakin meningkat serta munculnya penyakit yang disebabkan oleh keadaan malnutrisi

2) Pengetahuan orang tua masih terbatas tentang malnutrisi serta rasa ingin tahu yang besar dari orang tua tentang kondisi status nutrisi anaknya

3) Upaya preventif yang dilakukan belum maksimal untuk mencegaht erjadinya malnutrisi

Berdasarkan masalah tersebut makan penulis tertarik untuk melaksanakan IbM tentang deteksi dini mal nutrisi dengan metode ASPEN.

\section{METODE}

Sasaran pada kegiatan IbM terkait ini adalah anggota aisyah ranting Sumbang dengan jumlah 30 orang pada tanggal 15 Juni 2020 di Masjid An Nur Sumbang. Kegiatan dilaksanakan dengan pemberian materi dengan PPT dan dilanjutkan dengan stimulasi pemeriksaan menggunakan metode ASPEN dan pengukuran antropometri. Materi yang disampaikan tentang malnutrisi, metode ASPEN dan pengukuran antropometri. Kegiatan diawali dengan melakukan pre-test untuk mengetahui sejauh mana tingkat pengetahuan anggota ranting Aisyah tentang malnutrisi kemudian menjelaskan materi dan diakhiri dengan post-test.

\section{HASIL DAN PEMBAHASAN}

\section{1) Hasil}

Hasil pengetahuan anggota aisyah disajikan dalam tabel berikut ini

Tabel 1. Tingkat Pengetahuan AnggotaAisyahtentang mal nutrisi

\begin{tabular}{ccccc}
\hline \multirow{2}{*}{ Pengetahuan } & \multicolumn{2}{c}{ Pretest } & \multicolumn{2}{c}{ Postest } \\
\cline { 2 - 5 } & $\mathrm{N}$ & $\%$ & $\mathrm{~N}$ & $\%$ \\
\hline Baik & 18 & 13,3 & 24 & 20 \\
\hline Cukup & 8 & 26,7 & 6 & \\
\hline Kurang & 4 & 60 & & \\
\hline
\end{tabular}

Tingkat pengetahuan dikategorikan menjadi 3 yaitu baik, cukup dan kurang baik. Hasil menunjukan dari 30 anggota ranting aisyah dilakukan pre-test lebih banyak yang memiliki 
pengetahuan kurang yaitu 18 orang (60\%), cukup 8 orang $(26,7 \%)$ dan baik 4 orang $(13, \%)$. Sedangkan setelah dilakukan penkes didapatkan nilai post-test pengetahuan anggota ranting lebih meningkat dengan pengetahuan baik (80\%) dan cukup (20\%).

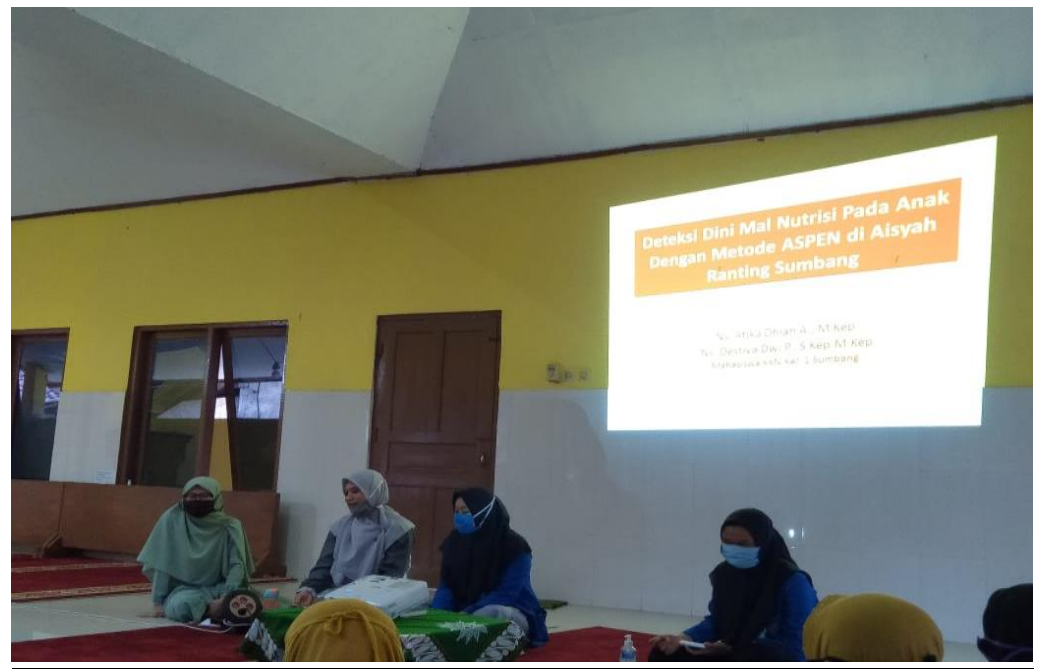

Gambar 1. Pemberian Materi

\section{2) Pembahasan}

Hasil dari kegiatan ini adalah anggota aisyah mendapatkan pengetahuan tentang malnutrisi dan penggunaan metode ASPEN untuk mendeteksi anak yang mengalami malnutrisi. Anggota aisyah merasa senang atas materi yang disampaikan karena mendapatkan pengetahuan yang baru serta dapat berperan aktif dalam deteksi anak malnutrisi baik untuk keluarga sendiri maupun lingkungannya. Metode ASPEN merupakan uji saring risiko malnutrisi yang dapat dilakukan oleh orang tua dengan diagnosis akhir ditentukan oleh tenaga medis yang akan memberikan tindakan tertentu bila terdiagnosis sebagai anak dengan risiko malnutrisi.

Status gizi yang baik merupakan syarat utama terwujudnya sumber daya manusia yang berkualitas, khususnya terhadap balita. Balita yang mengalami gangguan atau kekurangan gizi pada usia dini akan mengganggu tumbuh kembang, menyebabkan kesakitan dan kematian. Gangguan gizi pada umumnya disebabkan oleh kurangnya asupan gizi, infeksi dan yang paling penting adalah kurangnya perhatian orang tua (Junaidi, J., \& Noviyanda, 2016). Status gizi mempunyai peran yang sangat besar dalam menciptakan generasi yang bermutu dimasa yang akan datang. Status gizi berhubungan dengan kecerdasan anak, pembentukan kecerdasan pada usia dini tergantung pada asupan gizi yang diterima. Gizi kurang atau buruk pada masa bayi dan anak-anak terutama pada 14 umur kurang dari 5 tahun dapat menyebabkan terganggunya pertumbuhan jasmani dan kecerdasan anak.

Peran orang tua sangat penting dalam perkembangan gizi anak yaitu dengan pengetahuan yang baik maka orang tua dapat memberikan yang terbaik untuka naknya. Pengetahuan akan 
menjadi kekuatan bagi orang tua untuk dapat mencari strategi dalam mengakses pelayanan, mengatur kebiasaan-kebiasaan anak yang sangat menyusahkan dan mengatur emosional mereka terhadap keterbatasan anak. Pengetahuan (knowledge) adalah suatu hal yang berasal dari pancaindra dan pengalaman yang telah diproses oleh akal budi dan timbul secara sepontan. Sedangkan untuk sifat dari pengetahuan itu sendiri terdiri dari tiga hal yaitu spontan, intuitif, dan subjektif. Selain itu pengetahuan juga bersifat benar karena sesuai dengan realitas yang ada (Suryana, 2015).

\section{KESIMPULAN}

Program pengabdian kepada masyarakat dengan judul "Deteksi Dini Malnutrisi Pada Anak Dengan Metode ASPEN di Aisyah Ranting Sumbang memberikan manfaat sebagai berikut : pengetahuan anggota ranting aisyah sumbang tentang mal nutrisi meningkat, peningkatan pengetahuan tentang antropometri dan metode aspen dan anggota aisyah mendapatkan skill pengukuran antropometri dan metode ASPEN. Hasil dari pengabdian ini dapat menjadikan sebagai tindakan pencegahan anak yang terdeteksi mengalami ketidakseimbangan nutrisi, sehingga desa sumbang dapat menurun angka kejadian mal nutrisi di khususnya dan dikabupaten banyumas secara umum.

Saran kegiatan IbM untuk selanjutnya adalah upaya serupa dapat dilakukan pada kelompok yang lain untuk dapat memberikan pengetahuan tentang malnutrisi, monitoring harus selalu dilakukan setiap bulan terhadap anak untuk mengetahui tingkat pertumbuhan dan perkembangan serta kegiatan lain yang dapat menunjang peningkatan status gizi

\section{DAFTAR PUSTAKA}

Candra, A. (2017). Suplementasi Mikronutrien Dan Penanggulangan Malnutrisi Pada Anak Usia Di Bawah Lima Tahun (Balita). Journal of Nutrition and Health, 5(3), 159-165. https://doi.org/https://doi.org/10.14710/jnh.5.3.2017.159-165

Junaidi, J., \& Noviyanda, N. (2016). Kebiasaan Konsumsi Fast Food terhadap Obesitas pada Anak Sekolah Dasar Banda Aceh. AcTion: Aceh Nutrition Journal, 1(2), 78. https://doi.org/https://doi.org/10.30867/action.v1i2.14

Pricilia, M., Sampul, K., Yudi, A., Linnie, I., Program, P., Keperawatan, S. I., \& Kedokteran, F. (2015). HUBUNGAN DIARE DENGAN KEJADIAN MALNUTRISI PADA BALITA DI IRINA E BAWAH RSUP PROF. Dr. R. D. KANDOU MANADO. In JURNAL (Vol.

3 ,

Issue

$1)$. https://ejournal.unsrat.ac.id/index.php/jkp/article/view/6689 
Prita, S., Permatasari, Y., Gurnida, D. A., Departemen, A. C., Kesehatan, I., Fakultas, A., Universitas, K., Rsup, P., \& Sadikin, H. (2019). Kemampuan Alat Deteksi Dini Risiko Malnutrisi Menurut American Society for Parenteral and Enteral Nutrition pada Anak 660 Bulan oleh Orang Tua. In Sari Pediatri (Vol. 21, Issue 1). https://saripediatri.org/index.php/sari-pediatri/article/view/1484

Suryana, Y. (2015). Metode penelitian manajemen pendidikan. CV Pustaka Setia. 